\title{
Trapped in Reality: Justification and Capitalism in the Discourse of Reality TV Creators in Israel
}

\author{
Noa Lavie ${ }^{1}$ \\ THE ACADEMIC COLLEGE OF TEL AVIV-JAFFA \\ Lavie [AT] mta.ac.il
}

\begin{abstract}
This article examines the self-perception of Israel TV's reality show creators as a case study of how cultural industry employees perceive and cope with their work. On the one hand, creators of reality TV in Israel operate in a competitive and precarious working environment, and on the other hand, their work is criticized as inferior and culturally corrupting. Using a combination of cultural industries approach, sociological concepts, and in-depth thematic analysis of interviews with leading creators of the genre, this study sheds light on the justifications they employ and the way they are trapped in a capitalist industry.
\end{abstract}

Keywords: Television, Reality TV, Creators, Justifications, Capitalism

Many times the motivating factor that pulls you into doing more and more of this kind of work is money. These are prime-time projects with a lot of money changing hands ... and when it comes down to it, you've got a family to support. Again, it's not that I'm ashamed, although I sound as if I am. ...

Dan Weitzman, editor of Seasons 2 and 3 of The Voice

\section{Introduction}

This article uses the case of reality TV in Israel to explore the self-perception of reality TV creators in view of the presumed artistic inferiority of the reality genre ${ }^{2}$ and the precariousness of the television industry. ${ }^{3,4}$ Reality TV tends to be regarded as "trash" compared with other TV genres-especially drama series, which are often labeled artistic. ${ }^{5}$ This, as we shall see, is a distinction made by the television industry itself. Our interest lies in the self-image 
of leading reality TV creators in Israel and how they justify working in a field that dismisses their creative output as inferior.

Our findings will have relevance for television studies, which usually focus on content analysis, as well as the study of cultural industries and their workforce. While a solid corpus of research has addressed the precariousness of employment in the cultural industries, and television specifically (e.g., see Notes 3 and 4), ${ }^{6,7}$ little has been written about genre distinctions within the industry and how these distinctions impact its workforce.

We begin with a discussion of the artistic distinctions in the Western television industry, which align with neoliberal changes taking place in Euro-American television. Next, we clarify why reality TV in Israel is a suitable test case for understanding how reality creators see themselves and justify their work. After laying out the theoretical and empirical grounds for this article, we analyze input from some of the top reality creators in the industry, which sheds important light on their thinking.

\section{Artistic Distinctions in the Television Industry}

In recent decades, the Western television industry has begun to differentiate between quality TV and commercial trash (see Notes 2 and 5). This is partially due to the rise of quality drama series as a unique television genre. In the early 1980s, television dramas began to win academic and critical recognition, leading to their classification as a distinct genre. ${ }^{8,9}$ Later, in the late 1990s, Anglo-American TV drama productions began to be prebranded as quality television (see Note 9), ${ }^{10,11}$ particularly those aired on the celebrated American cable television channel HBO.

Meanwhile, online television streaming sites such as Netflix, with its political drama House of Cards and jail drama Orange Is the New Black, and Hulu, with its dystopia The Handmaid's Tale, have become the spearhead of the global television market. With the spread of this institutionalized concept of quality TV and its impact on artistic self-esteem (see Notes 2 and 5), the attitude toward more commercial productions has become radical, and today they are regarded as low quality (see Note 2). One of the most criticized television genres of all is reality TV.

Before the evolvement of SVOD (Streaming Video on Demand), ${ }^{12}$ the global TV market was dominated by reality shows. ${ }^{13,14}$ Categorizing reality TV is no simple matter because the genre spans fiction and documentary programs, soap operas, game shows, talk shows, and even advertising. ${ }^{15}$ Over time, reality TV has become a generic label applicable to anything from talent contests, desert island endurance competitions, and dating games, to social experiments in which contestants are locked in a house with strangers and filmed $24 / 7 .{ }^{16}$ In journalistic circles, reality TV is usually dismissed as low quality, if not outright trash ${ }^{17}$ compared with made-for-TV drama, which, as mentioned above, is sometimes hailed as high quality and artistic (see Note 2). 18,19

Reality TV, which emerged in the United States in the wake of changes in the American television industry, ${ }^{20}$ has been defined as a commercial genre governed by capitalist market rules. ${ }^{21}$ In the early 2000 s, as major American networks shifted from analog to digital technology, reality TV and format television became more widespread (see Note 13). Low-cost 
reality formats such as The Voice and Master Chef became emblematic of the neoliberal marketing strategy of the American and European television industries. ${ }^{22}$ This link between neoliberalism and reality TV led to reality TV being branded the "horror theater of neoliberalism" (See Note 21) and charges that reality TV was inauthentic (see Note 17). ${ }^{23,24}$

As such, many critics claim that under the pretense of authenticity, reality TV promotes aggressive competition (see Note 21), voyeurism, and invasion of privacy, which are frequently regarded as hallmarks of accelerated capitalism and neoliberalism. ${ }^{25}$ Furthermore, numerous studies have been written about the ethical problems inherent in the genre and its use of problematic strategies vis-à-vis the contestants of the shows and the audience (see Notes 21 and 24). ${ }^{26,27}$

These views of reality TV enhanced the binaric socially constructed differentiation between drama series which were viewed as quality TV and even artistic (see Note 5) versus the perception of reality TV as trash (see Note 2). This social construction resulted in an institutionalized hierarchy between two schools of television production-one that produces "quality" and another that produces "trash."

It was Pierre Bourdieu ${ }^{28,29}$ who theoretically conceptualized the distinction between the two poles of what he called the field of cultural production. In every field, social agents fight over positions. Bourdieu differentiated between a mass capitalist production pole with its fight over financial capital and "restricted" artistic production pole in which the fight is over symbolic capital such as artistic recognition. Over the last two decades, the field of television production has been socially constructed to distinguish, much like the Bourdieusian distinction, between commercial genres such as reality TV, regarded as inferior, and artistic and autonomous television production, that is, quality TV drama (see Note 5).

Reality TV, while highly criticized (see Notes $21,24,26$, and 27), has nevertheless become an important engine of global television in an age of precarity. ${ }^{30}$ It is true that the commercial television industry enjoys a glamorous image in everyday social discourse. ${ }^{31}$ However, contemporary studies show the industry, like many cultural industries, is in the throes of an economic and employment crisis (see Notes 3 and 4). Those working or seeking to work in commercial television find themselves in an unstable work environment where competition is tough and anxiety, emotional distress, and financial hardship are common (see Note 7).

Given that the genre is socially frowned upon despite being an anchor of employment in the television industry (See Note 30), reality creators are placed in an awkward, apologetic position. "The criticism comes with the format; it's a package deal," the former chief editor of the Israeli Big Brother, Yoram Zak, told Israeli Firma magazine in an interview for its 2012 Independence Day edition. ${ }^{32}$

In light of the above, this article aims to study the self-perceptions of reality TV creators visà-vis the constructed artistic inferiority of the genre and the looming problem of job instability. Taking the Israeli reality TV creators as a test case, ${ }^{33}$ we look at how high-profile members of the industry relate to their work and work environment.

It is important to note that these industry "aristocrats" are employed in a component of the TV industry that is less artistically valued (see Notes 2 and 5). ${ }^{34,35}$ Hence, their aristocracy is defined primarily by high income. An interesting question is how these creators view their 
work compared with the more artistically hailed products of the Israeli television industry, that is, quality TV drama (see Note 5).

\section{The Case of Israel}

In recent years, Israeli TV, a small industry in the Middle East, has become a leading exporter of a variety of TV content that includes dramas, TV shows for children, reality TV, game shows, and so on (see Note 30). Despite this global success, the field of Israeli TV production suffers from a high degree of instability. ${ }^{36}$ As an industry characterized by competition and struggles of creators over work, prestige, and perceptions of artistic quality, ${ }^{37,38}$ Israel presents an interesting case study.

The Israeli TV industry makes an institutionalized and formal distinction between reality TV and other TV genres. This distinction is the result of economic changes introduced in the Israeli TV market. In 1990, after twenty-five years of a state monopoly by a single channel (channel1), theSecondAuthorityLawwaspassed, culminatingintheestablishmentoftwopubliccommercial channels (Channel 2 and later, Channel 10). The inauguration of commercial television, and cable and satellite services in Israel spurred an increase in original Hebrew programming. However, most of the productions were low-cost, that is, talk shows, game shows, ${ }^{39,40}$ and soap operas, ${ }^{41}$ and were thus perceived as culturally and artistically inferior. ${ }^{42}$ Flooding Israeli television with low-quality productions conflicted with the Second Authority's declared cultural goals, one of which was the promotion of "high-quality" Hebrew culture. Consequently, a clause was added to the Second Authority Law in 2000 to define "elite" programming and establish the franchisee's quotas and obligations with respect to this genre (see Note 5).

Reality TV was not classified as an elite genre due to the relatively low production costs compared with drama. The premise of the law is that the more money invested in a genre, the higher its quality. Nevertheless, reality shows have become a staple of public-commercial television in Israel, much more so than in other countries. ${ }^{43}$ Despite the high ratings of reality shows in Israel, a survey commissioned by the Second Authority in 2006 found that a significant segment of the public (27.1 percent of the respondents) disapproved of such programs. ${ }^{44}$ Most viewers regarded the genre as immoral and of low quality (see Note 44). Israeli television critics feel the same way (see Note 2).

In 2015-2016, for example, there was an outcry over scenes of verbal and physical violence on Big Brother. The show, then in its seventh season, was deemed "highly unethical," and media critics wondered how "the creators could look at themselves in the mirror in the morning". ${ }^{45}$ In response, the Second Authority for Television and Radio tried to cut back on the volume of reality TV, declaring it a socially undesirable genre. ${ }^{46}$

Because the Israeli TV market is a small market in which jobs are scarce and competition tough (see Note 36), many TV creators feel they must work in reality to survive. This makes the Israeli case appropriate for analyzing reality creators' self-perceptions, coping mechanisms in view of the industry's precarious conditions, and response to social criticism. Furthermore, focusing 
on Israeli television can be useful for understanding the world of non-Anglo-American cultural creation, which traditionally attracts less academic attention (see Note 30).

\section{Pragmatic Sociology: Studying the Cultural Industries' Labor Force}

In industrial and capitalist countries, the cultural industry workplace functions as an important and multifaceted arena for the tug of war between amassing capital (or enough to produce more cultural artifacts) and the desire for creativity and creative freedom. ${ }^{47}$ The creative urge is fueled by a combination of motives: self-expression, pleasure, public recognition, and even arrogance. ${ }^{48}$ Cultural industries thus constitute a complex and competitive work environment in which an array of pragmatist strategies are employed (see Note 47).

To investigate these strategies in a field where social agents-in our case, reality creatorsmust fight over their position in the field (see Note 29), let us look at the pragmatic sociology of Luc Boltanski. ${ }^{49}$ According to Boltanski and Thévenot, ${ }^{50}$ day-to-day interactions of individual social actors are governed by six regimes, or paradigms, of social justification. These social justifications are used by social agents in a versatile manner, depending on time and place. Boltanski and Thévenot (see Note 50) distinguish between the inspired world, a regime of justification that emphasizes creativity, uniqueness, and freedom combined with risk-taking; the domestic world, a regime of justification emphasizing hierarchy and self-worth that attributes great importance to social values and conventions; the world of fame, which emphasizes public opinion and uses social visibility as an index; the civic regime, where the value of the individual is determined by being part of a collective with an emphasis on the "greater good" of the group or society; the market regime, where actions are spurred by the desire of individuals to accumulate assets, accentuating competition and economic gain; and the industrial regime, which highlights professionalism, efficiency, and the ability to present a plan and achieve goals.

Applying Boltanski and Thévenot's set of social justifications, we will analyze the discourse of the creators and evaluate our findings in the context of the cultural industries -in this case, the television industry. Such an approach will provide deeper insights into the day-to-day coping strategies of those who work in the industry.

\section{Methodology}

This article is based on semi-structured in-depth interviews ${ }^{51}$ with ten of Israel's top reality creators. Before further explaining the research methodology, it is important to note that the interviewees were Jewish-citizens of Israel, and all except one were male. This is relevant in that it exemplifies how Israel's cultural industries, including television, are a product of the political, racial, ethnic, and national divide in Israel. Israel is a state which is defined as Jewish, but 20 percent of its citizens are Arab and identify as Palestinian-Israeli. ${ }^{52}$ This sector has close to zero representation in cultural industries and television. ${ }^{53}$

Women are also underrepresented in creative positions in the Israeli television industry, as they are in the rest of the Western world. ${ }^{54}$ The survey group is thus characteristic of Israeli 
society as a whole. The interviewees are not only the "aristocrats" of the television industry in Israel, but also represent its gender and ethnic elite. Although Israel is a country embroiled in national conflict, stratification in its cultural industries is similar to that in Anglo-American fields of production. ${ }^{5}$

Initially, the process of recruiting interviewees was impeded by the difficulty of access that typifies high-profile industries, but the problem was eventually resolved through personal connections with some of the subjects. ${ }^{56}$ Thereafter, participation was achieved by snowball effect. Face-to-face interviews lasted an hour and a half to two hours. Except for one subject, everyone agreed to be identified. The interviewees were: (1) Yael Avneri, creator and editor of 24/7: The Next Generation, in which singles secluded in a villa are filmed around the clock. ${ }^{57}$ Avneri also edited the Israeli version of Beauty and the Geek, pairing "dumb blondes" with socially inept men, and TLV, which tracked young women seeking their fortunes in Tel Aviv. Early in her career, Avneri was involved in the Israeli production of Survivor; (2) Yoram Zak, formerly the chief editor of Big Brother; (3) Dan Weitzman, chief editor of the second and third seasons of The Voice; (4) Orna Ben-Dor, creator and editor of Me'usharot, based on America's Real Housewives that documents the lives of rich women ${ }^{58}$; (5) Yoav Zafir, chief editor of Kokhav Nolad, the Israeli version of American Idol, scouting for singers; (6) Tsedi Sarfati, a judge on Kokhav Nolad and director of several of the show's specials; (7) Avi Yaffe, who edited Haravak, the Israeli version of The Bachelor with popular singer Dudu Aharon as the eligible bachelor, and helped produce Survivor, Master Chef, and Beauty and the Geek; (8) Rani Sa'ar, director of Bollywood, an Israeli talent show filmed in India and broadcast via the satellite channel YES, and outdoors director of Take Me, Sharon, the Israeli version of The Bachelorette; (9) Ami Glam, creator of Ad Sof Ha'olam, Israel's version of Till the End of the World, a reality show about divorcees, for Channel 10; and (10) an assistant creator of Big Brother who asked to remain anonymous.

The interviewees were involved in many aspects of the creative process (editing, screenwriting, directing), but are all categorized as "creators." In the cultural industries, creative work is perceived as a team effort, and each aspect has its own importance. ${ }^{59}$ The chosen method of analysis was thematic. ${ }^{60}$ This method identifies data patterns and examines their impact across different discourses and social constructs.

\section{The Discourse of Reality TV Creators and What Lies Beneath}

An analysis of the interviews revealed a range of conflicting concepts and models of selfperception and self-justification: notions of freedom versus economic constraint, civic responsibility versus moral dilemmas and a sense of victimhood. For the sake of clarity, the analysis is divided into themes, although some may overlap.

From Civic Responsibility to Economic Justification

It starts out as a way of making a living, you know, but it's not just that. I mean, I could have earned money doing other things, but maybe not as much as from reality. I definitely had other options but 
they offered me Me'usharot, and I have to say that I started out using the same tools as [I used] for documentaries. As I thought about how I would do it and what kind of content I could pack in, I decided to make it more feminist ... (Orna Ben-Dor, interview)

Throughout the interviews, the creators employed a discourse of justification (see Note 50). The view of reality TV as an arena of creativity and freedom was especially prominent. For example, even though Orna Ben-Dor makes it clear that making a living was her primary consideration and reality TV was profitable compared with other jobs in the volatile Israeli television market (see Note 36), she insists it was a choice. Other options were available, but she preferred to work on a reality show. Ben-Dor seems to feel a sense of relative freedom of choice, in what is normally perceived as a precarious working environment (see Note 7). According to Boltanski and Thévenot (see Note 50), this presumption of freedom is a specific habitus related to the justification regime of the inspired world, where social agents justify their deeds in the name of art and creativity.

However, Ben-Dor also emphasizes individual commitment to the collective. She connects to her feminist identity and presents her work as the product of commitment to a whole that is greater than the sum of its parts. In making her work "feminist," Ben-Dor portrays herself as contributing to the larger good of her fellow women and to society as a whole. This resonates with the justification regime of the civic world (see Note 50), in which one's actions are viewed as benefiting society. At the core, it seems to be a coping strategy triggered by the moral panic that surrounds reality TV and insinuations that it is not only a "low quality" genre but also socially harmful. ${ }^{61}$

These sentiments regarding civic responsibility appear in the discourse of other creators, as well. Dan Weitzman, creator of The Voice, says,

... I have moral responsibilities. When Sahar Azimi [an HIV-carrier] came in for an audition ... the biggest issue was whether or not to characterize him as gay. When we floated it [at the audition], it was only an experiment ... In the end, we decided not to say a word about his being gay ... so as not to create a link between AIDS and homosexuality, which has a stigma attached to it, for the sake of the public. (Weitzman, interview)

Weitzman's statement highlights what he considers his moral responsibility not to perpetuate the widespread stereotype and automatic assumption that all HIV carriers are gay. Weitzman, even more than Ben-Dor, expresses the belief that reality television is justified if it normalizes political, gender, and ethnic minorities. Moreover, Weitzman sets himself up as the moral teacher of the masses in a manner consistent with the elitist approach to reality show audiences while presenting himself as a fighter for fair representation of minorities and an anti-elitist. His self-justification may come out of the need to justify his work vis-à-vis the critique of reality TV as immoral. However, he also employs a civic world justification (see Note 49) while adopting an elitist stance.

Ami Glam uses the same kind of justification. He argues that

reality TV presents Israel in all its diversity-the common people-but not in the negative sense of the word; in a good sense. It takes these people and puts them on the screen. That is a very powerful change. Because until reality shows began, people in the television industry could select who 
represented the nation... they were all of the same ethnic origin [European Jews]. Reality television ... breaks down this hegemony. (Glam, interview)

In Ami Glam's view, reality programming brings people who were once excluded due to racial bias to the screen-specifically Mizrahi Jews (Jews of Middle Eastern or North African origin) and Palestinian citizens of Israel. ${ }^{62}$ According to Glam, this gives the genre subversive and liberating political significance. Glam thus perceives reality TV as contributing to the common good, much like Ben-Dor and Weitzman.

In the civic world paradigm (see Note 50), the individual becomes worthy by aligning his private interests with the common good. Here, pursuit of the common good is portrayed as multicultural tolerance; however, it seems that this tolerance is recruited by the creators to justify their work in a market that preserves capitalist hegemony: It nurtures personal gain and individualism while exploiting diversity as a tool for boosting ratings and capital.

However, some creators forgo the "civic world" justification, and speak openly and unapologetically about the financial returns of reality television, which fits in with the "market regime" paradigm (see Note 50). Tsedi Sarfati, for example, argues that reality shows serve no moral or civic goal:

There is no other goal apart from ratings ... All we want is for viewers to be glued to the screen, and if an interesting personal story or talent does the trick, that's enough. (Sarfati, interview)

Sarfati admits that he began to work in reality shows for money, despite his reputation as a notable director of plays and musicals. "I needed the work," said Sarfati. "In this business, you're always on the lookout." Sarfati speaks bluntly about the consequences of working in the cultural industries under conditions of precarity. He also claims that the casting process of reality shows is not authentic but rather a function of rating needs. As the oldest and most experienced of the interviewees, Sarfati does not try to pass off his work as a contribution to the common good. He makes it clear that his goal is financial, while citing the precariousness of the industry as a justification.

\section{Morality, Passivity, and Domestic Love}

Sarfati also speaks about manipulation as a constant in reality TV, a component that many of the interviewees find disturbing. As Avi Yaffe, creator of The Bachelor, puts it,

Intrigue is not my thing. I suffered and had a hard time morally because these people trusted me. What I do best is draw people in. I embrace them and become their anchor. In good and bad times, they come to you-and then you go and play tricks on them. You win their trust and exploit it. I wasn't happy about it. I felt it was going overboard. (Yaffe, interview)

Yaffe's remarks reveal a serious ethical dilemma in reality TV: the manipulation of contestants in a way that may be harmful, for the sake of pumping up viewer interest and ratings. This is a widespread problem in the industry and imposes an emotional and ethical burden on creators (see Note 7). Yaffe resolved the issue by trying to make the Israeli version of The Bachelor as "funny and humoristic" as possible, with less manipulation. 
Another interesting point is Yaffe's portrayal of himself as a passive victim of the reality industry. "I suffered ... I wasn't happy about it," says Yaffe. This reversal, in which Yaffe himself becomes a victim of the reality system, has been widely noted (see Note 27). It is a rhetorical justification that subconsciously enables Yaffe to continue working in the industry. It might be that casting himself as passive and suffering frees Yaffe from his feelings of guilt toward the show's participants. On the contrary, it reflects the precariousness of the profession. Sometimes one must accept whatever work is available.

Orna Ben-Dor celebrates the commercial success of Me'usharot but also resorts to apologetics:

... I got hooked on this genre because there are nice things about it... it's funny and fun and supposedly just nonsense, although it really isn't. It is lightweight, of course ... but mostly I got hooked on the public exposure, being broadcast on prime time TV and becoming part of the entire Israeli street experience ... My main job and the goal of the show is to generate ratings and entertain the television audience as a whole.

Ben-Dor admits that she became addicted to the show's success and to being a center of public attention. On the one hand, she is pleased with her achievements, but beneath the surface is self-criticism at being hooked on the "success drug." Moreover, she accepts the role assigned by the channel owners-that of generating ratings, that is, maximizing economic profit-and portrays herself as passive, in contrast to the perception of freedom expressed earlier.

Ben-Dor's comments attest to identification with the system and the capitalist celebration of personal success, and align with Boltanski and Thévenot's world of fame paradigm (see Note 50). Yet the word "hooked" hints to a certain distress. The creator enjoys the buzz of victory that comes with chalking up ratings, yet feels like a drug addict, trapped in the clutches of the capitalist regime. In this respect, she is very much like reality TV contestants, trapped in the confines of the show.

Yael Avneri describes the price one pays working for the capitalist market system:

... There is one scene I remember in TLV where I literally crossed my own line. There was a fight between two female contestants, and it was great stuff. I said, "Wow, this is good for three whole episodes." It wasn't a trashy fight. You don't get this kind of thing every day. But when the fight was over, one of them, a sweet girl, broke down and cried. She said, "I want a cigarette." And I said to myself, "She's crying now and falling apart. I need her for a testimonial [a confession in front of the camera]. I need her crying. Tears during a testimonial are the best." So I told her to go upstairs to where testimonials are filmed. She said she needed a moment to calm down, "I want to talk to my mother; I need a smoke." I told her no. I screamed at her and said, "It's not your decision when we film and when we don't." The camera was on her, to show that everything was recorded, that I was the one who called the shots. Would the scene have been bad if she hadn't cried? She was such a show-stopper, it didn't matter if she cried or not. But my hysteria as an editor, the idea that I had to have a crying testimonial, got the better of me. I forced her to go upstairs and as soon as she sat down, I got a grip on myself. As the production assistant began to interview her, I realized how manipulative it was ... In the end, I edited the scene out. (Avneri, interview) 
This quote reveals the pressure placed on reality show creators to generate content that stirs up viewer emotions and boosts ratings (see Note 6). In fact, all the interviewees admitted to a certain amount of manipulation. However, like Yaffe and Avneri, most claimed that their personal sense of morality prevented them from extreme or harmful manipulation. At the same time, they portrayed themselves as trapped in a capitalist system governed by rules of the marketplace.

Also interesting is Avneri's use of the passive-the idea that filming a crying testimonial "got the better of me." Like Ben-Dor, Avneri also uses the rhetoric of an addict. The creators of reality TV are able to live in a capitalist system, but decline personal responsibility because they too are imprisoned and must perform, much like the contestants themselves. This perception of passiveness blinds them to the fact that they are active participants in reinforcing the competitive and polarizing capitalist discourse (see Note 21).

Avneri's statements also align with another justification regime proposed by Boltanski and Thévenot (see Note 50)-the domestic world paradigm, built on hierarchies found in the family. As in a family relationship, Avneri boosts her self-worth by relating to the contestant as a child. She assumes the role of mother, an authority figure who scolds and then saves the contestant/child. In some way, this justification, along with the argument that she, too, is a victim, makes her work more palatable.

The domestic world paradigm also crops up in the interview with Yoav Zafir:

I think Kokhav Nolad [A Star is Born] is a show where the contestants are entirely surrounded by love. I am not out to ridicule the contestants or have people at home treat them condescendingly, which I think is a big part of the success of reality shows: The audience looks at this person and says "I'm better than him. What a jerk. What an idiot." (Zafir, interview)

Zafir distances himself from other reality show creators whom he claims ridicule the contestants to satisfy the audience and increase ratings. He sees himself as more moral because of the "love" he lavishes on the contestants. Loving and taking responsibility for the singers is portrayed by Zafir as a moral act which shields them from the audience's critical eye. Zafir, like other creators, adopts an elitist approach toward the audience and contestants, treating them like children in need of fatherly guidance.

\section{Quality and Authenticity}

Most of the creators interviewed for this study perceive their work as high quality and artistic despite the barrage of social criticism (see Note 61) and the fact that the television industry distinguishes between reality shows and more "worthy" genres.

Orna Ben-Dor, for example, sees little difference between working on a reality show and producing a documentary. Moving to reality after making Because of that War (1998), a highly regarded documentary about Israeli musicians Yehuda Poliker and Yaacov Gilad, both children of Holocaust survivors, Ben-Dor insists that reality involves as much creativity as quality programming. She does not perceive her reality work as inferior and asserts that in the context of the television industry, "both genres require the same craftsmanship and are qualitatively equal." 
Dan Weitzman makes a similar point, describing reality TV as television of the highest caliber:

This genre is always being mocked and belittled ... but I'm telling you it requires extremely complex skills of the kind that documentary creators take pride in, like telling a story based on a rough cut ... That's what I really learned from Pa'am Bahayim [Once in a Lifetime, a docu-reality show filming Israeli celebrities in environs that clash with their public image]. I learned to create a story on location that later goes to the editing room, and I realized this is where I wanted to be. (Weitzman, interview)

Weitzman highlights the professional, ostensibly objective aspects of television work, such as editing and scriptwriting-while defending reality TV. Weitzman and Ben-Dor express the habitus of the "industrial world" justification regime (see Note 50), where social agents adopt a discourse of professionalism to justify their decisions. Moreover, Weitzman employs phrases such as "creating a story," accentuating his creative role in a way that contradicts the perception of reality TV as unscripted and hence of no creative value (see Note 18).

Yoram Zak, until recently head creator of Big Brother, further clarifies,

I think Big Brother contains texts that no one could write and ... scenes you would never see in any drama. That's why drama creators are jealous and try to learn how to leverage their actors by watching reality. It's because there is something so incredibly authentic in these shows. Angry people, people in love, people unaware of the cameras at a particular moment... Of course, one could argue about the degree of authenticity, but there is stuff no one could write... It gets into places you never see. These things don't appear on edited (drama) television ... and not in films either. (Zak, interview)

For Zak, reality shows are more authentic than television dramas and cinema, genres typically defined as art forms (see Note 5). ${ }^{63}$ One of the constructed attributes of a quality TV drama is authenticity (see Note 5). However, authenticity is highly contested when it comes to reality TV (see Note 14). Insisting on the authenticity of reality TV despite claims of its inauthenticity is yet another coping strategy that allows creators to justify working in the industry without giving up their self-identification as artists. It fits in with the "inspired world" justification regime (see Note 50).

One of the assistant creators of Big Brother offers this comment on the authenticity of reality TV:

I think all the criticism [of reality shows] boils down to bourgeois tongue-clucking. Watching Big Brother is a kind of anti-bourgeois act because you turn on the television and what you see is wild, plain wild. (Anonymous interview)

Big Brother, and reality television in general, is defined as anti-bourgeois because of its unsophisticated style, which ultimately taps into the broader debate over authenticity (see Note 14). The creators interviewed for this study are very much aware of the criticism of reality TV. They concur that the shows are manipulated through editing and the contestants are subject to manipulation. Yet most insist that these shows contain an authentic core that legitimizes the genre and even adds an aura of artistic quality (see Note 29). 
According to Rani Sa'ar,

Reality shows do have some value. Even Big Brother, I think, has a certain value, since ultimately, the winner is the one who was true to himself-the one who comes across as most real and authentic, and says what he thinks. We see that the contestants who reach the finish line in Big Brother are the ones who are the most authentic and true. (Sa'ar, interview)

Sa'ar's remarks reflect the discourse within the reality genre itself, where the contestant who stands out as a real individual is the one who deserves to win. ${ }^{64}$ Neoliberalism emphasizes the role of the individual and his personal journey in a capitalist environment (see Note 21). In their insistence that reality shows convey an authentic truth, the interviewees apparently subscribe to this approach, which aligns with outlook of the cultural industries that in the final analysis all creativity is art. ${ }^{65}$ As such, the justifications employed by reality creators are not mere self-persuasion but part and parcel of the habitus of the cultural industries (see Note 29). Drawing on this habitus, a whole host of strategies and tactics are employed in a bid to justify themselves and their work.

\section{Summary and Discussion}

In this article, we have traced the self-perception of reality TV creators in the face of social opprobrium. We have applied the pragmatic sociology of Boltanski and Thévenot (see Note 50) to the study of cultural industries and attempted to understand how all this ties in with the precarious nature of the television industry. Using reality TV in Israel as a case study, we have found that creators use a variety of pragmatic justifications to rationalize their work in the reality industry and portray themselves as artists, moral leaders, and professional craftsmen.

While all six justification regimes came up in the interviews, the most recurrent justifications were the "inspired world" paradigm, in which social agents work for "the sake of art" and regard themselves as creative artists, and the "civic world" regime, in which they justify their work as a contribution to the common good-in contrast to the way reality TV is actually perceived, socially and artistically.

Reality TV creators seem to be aware of the socially constructed difference between quality television genres, which are regarded as "art," and reality TV. Yet they highlight the authenticity and creativity of reality TV and do not hesitate to place their work on a par with quality genres like drama and documentaries. In trying to resolve the moral dilemma in which they find themselves, they use apologetic and passive terminology, on the one hand, and claim to feel love and responsibility for the contestants, on the other. However, beneath this facade of personal caring may lie an elitist approach in which they treat both the public and the contestants as children in need of guidance.

Furthermore, the arguments employed by these reality creators go beyond self-justification. They are rooted in the hegemonic capitalist discourse that defines capitalism as an ideology which allows society to free itself from the old elites and work for the common good. A competitive capitalist economy, of which reality TV is part, thus becomes a springboard for individuals and society to be freer and more prosperous. The creators believe in the success of the "authentic" contestant, thereby reinforcing the widely held capitalist view of individual responsibility and the importance of carving out an authentic path in the world (see note 64). To quote Boltanski 
(see Note 49), they are "experts" who have internalized capitalist ideology and become marketers and disseminators of an ideology that portrays competition as individualism.

In this way, not only reality TV but also capitalist ideology becomes morally justified. The creators act as full-fledged agents of the capitalist system. They depend on capitalism to thrive (see Note 49). As employees of a competitive and uncertain work environment, they play an important role not only in the television industry but also in preserving the capitalist hegemony. The justifications they employ as they grapple with the constraints of their jobs and a torrent of public criticism reflect not only the habitus of specific regimes of justification (see Note 50) but, above all, the capitalist hegemony and its primacy in their worldview. Creators of reality TV in Israel thus become participants in a complex social game that is not so different from the games in which the reality show contestants compete. Captive in a capitalist industry and perpetuating the dominant hegemonic discourse, one is hard-pressed to see them as free.

${ }^{1}$ Noa Lavie is senior lecturer and head of the Political Communication Unit at the School of Government and Society, The Academic College of Tel Aviv-Jaffa. Dr. Lavie has published in leading international journals on the topics of cultural taste, cultural industries labor force, and television regulations.

${ }^{2}$ Noa Lavie, "'Reality' Television Critique in Israel: How 'Quality' Became 'Morality"' Cultural Sociology 10 (4, 2016): 502-22.

${ }^{3}$ Vicki Mayer, "New Television and Media?" Television E New Media 12 (2, 2011): 95-100.

${ }^{4}$ Mark Deuze, "Work in Media," Media Industries 1 (2014), https://quod.lib.umich .edu/m/mij/15031809.0001.201/--work-in-the-media?rgn=main;view=fulltext.

${ }^{5}$ Noa Lavie, "Constructing the Israeli 'Quality' Television Series as an Art Form," Media Culture and Society 37 (1, 2015): 19-34.

${ }^{6}$ David Hesmondhalgh and Sarah Baker, "Creative Work and Emotional Labor in the Television Industry," Theory, Culture E Society 25 (7-8, 2008): 97-118.

${ }^{7}$ David Hesmondhalgh and Sarah Baker, "A Very Complicated Version of Freedom: Conditions and Experiences of Creative Labour in Three Cultural Industries," Poetics 38 (2010): 4-20.

${ }^{8}$ Robert J. Thompson, Television's Second Golden Age: From Hill Street Blues to ER (Syracuse, NY: Syracuse University Press, 1997).

${ }^{9}$ Janet McCabe and Kim Akass, eds. Quality TV: Contemporary American Television and Beyond (London: I.B. Tauris, 2007).

${ }^{10}$ Mareika Jenner, "Binge-Watching:Video-on-Demand, Quality TV and Mainstreaming Fandom," International Journal of Cultural Studies 20 (3, 2015): 304-20.

${ }^{11}$ Mareika Jenner, "Is This TVIV? On Netflix, TVIII and Binge-Watching," New Media E Society 18 (2, 2016): 257-73.

12 Mareika Jenner, "Binge-Watching:Video-on-Demand, Quality TV and Mainstreaming Fandom," International Journal of Cultural Studies 20 (3, 2017): 304-20.

13 Ted Magder, "Television 2.0: The Business of American Television in Transition," in Reality TV: Remaking Television Culture, ed. Laurie Murray and Susan Ouellette (NY: New York University Press, 2009), 141-64.

${ }^{14}$ Motti Neiger, "Cultural Oxymora: The Israeli Idol Negotiates Meanings and Readings," Television \& New Media 13 (6, 2012): 535-50. 
${ }^{15}$ Misha Kavka, Reality TV (Edinburgh: Edinburgh University Press, 2012), 6.

${ }^{16}$ Susan Murray and Laurie Ouellette, Reality TV: Remaking Television Culture (NY: New York University Press, 2009.

${ }^{17}$ Mina Aslama and Mervi Pantti, "Flagging Finnishness: Reproducing National Identity in Reality Television," Television \& New Media 8 (2007): 49-67.

18 Jason Mittell, "Complex TV": The Poetics of Contemporary Television Storytelling (NY: New York University Press, 2015).

${ }^{19}$ Robin Nelson, "Quality Television: "The Sopranos Is the Best Television Drama Ever ... in My Humble Opinion," Critical Studies in Television 1 (1, 2006): 25.

${ }^{20}$ Chad Raphael, "The Political-Economic Origins of Reali-TV," in Reality TV: Remaking Television Culture, ed. Susan Murray and Laurie Ouellette (NY: New York University Press, 2009), 119-36.

${ }^{21}$ Nick Couldry, "Reality TV, or the Secret Theater of Neoliberalism," Review of Education, Pedagogy and Cultural Studies 30 (2008): 3-13.

${ }^{22}$ Silvio Waisbord, "McTV: Understanding the Global Popularity of Television Formats," Television E New Media 5 (4, 2004): 359-83.

${ }^{23}$ June Deery, "Reality TV as Advertainment," Popular Communication 2 (1, 2013): 1-20.

${ }^{24}$ Beverly Skeggs, "The Moral Economy of Person Production: The Class Relations of Self-Performance on Reality Television," The Sociological Review 57 (4, 2009): 626-44.

${ }^{25}$ Ernest Mathijs, "Big Brother and Critical Discourse: The Reception of Big Brother Belgium," Television E New Media 3 (3, 2002): 311-22.

${ }^{26}$ Tony Krijnen and Ed Tan, "Reality TV as a Moral Laboratory: A Dramaturgical Analysis of 'The Golden Cage," Communications 34 (2009): 449-72.

${ }^{27}$ Nick Couldry and Jo Littler, 'Work, Power and Performance: Analyzing the "Reality' Game of The Apprentice," Cultural Sociology 5 (2011): 263-79.

${ }^{28}$ Pierre Bourdieu, Distinction: A Social Critique on the Judgment of Taste (Boston, MA: Harvard University Press, 1984).

${ }^{29}$ Pierre Bourdieu, The Field of Cultural Production (Oxford: Polity Press, 1993).

${ }^{30}$ Tasha Oren and Sharon Shahaf, Global Television Formats: Understanding Television across Borders (NY: Routledge, 2013).

${ }^{31}$ Stefano Harney, "Creative Industries Debate: Unfinished Business: Labour, Management, and the Creative Industries," Cultural Studies 24 (3, 2010): 431-44.

${ }^{32}$ Lior Averbach, "We Wanted to Bring a Woman in Her Eighth Month into the House and Have Her Give Birth There. I Believe It Will Happen One Day," Globes, April 23, 2012. http://www.mako.co.il/tv-bigbrother/season4-articles/Article8314ae45a9fd631006.htm. (in Hebrew)

${ }^{33}$ Robert K. Yin, Case Study Research: Design and Method. 4th ed. (Thousand Oaks, CA: SAGE, 2009).

${ }^{34}$ Noa Lavie and Alexander Dhoest, "Quality Television in the Making: The Cases of Flanders and Israel," Poetics 52 (2015): 64-74.

${ }^{35}$ Noa Lavie, "'Justifying Trash': Regulating Reality TV in Israel," Television \& New Media 20 (3, 2019): 219-40.

${ }^{36}$ Haim Hagai and Roy Davidson, "It's Hard to Dream Anymore: The Career Structure of Screenwriters in the Israeli Film and Television Industry," Media Frameworks 13 (2014): 63-84. (in Hebrew) 
${ }^{37}$ Lavie and Dhoest, "Quality Television in the Making."

${ }^{38}$ Lavie, "Reality' Television Critique in Israel."

${ }^{39}$ Oren Tokatli, Communication Policy in Israel (Tel Aviv: The Open University, 2000). (in Hebrew)

${ }^{40}$ Noam Yuran, Channel 2-The New Statehood (Tel Aviv: Resling, Patish, 2001). (in Hebrew)

${ }^{41}$ Ayelet Bar-Gur, Israeli Soap Opera, from Ramat Aviv Gimmel to Ha'alufa (Tel Aviv: Resling, 2011), 67-182. (in Hebrew)

${ }^{42}$ Tony Bennett, "Distinction on the Box: Cultural Capital and the Social Space of Broadcasting," Cultural Trends 15 (2006): 193-212.

${ }^{43}$ Nati Tucker, "Reality Dominates Television in Israel," The Marker, May 23, 2013. http://www.themarker.com/advertising/1.2027656. (in Hebrew)

${ }^{44}$ Gabi Waiman, Yonatan Cohen, and Hermann Shitrit, "Reality Shows in Israel: From Reality to Imagination, Innocence to Manipulation, Public to Private." Research Report for the Second Authority. 2007. http://www.rashut2.org.il/editor/ uploadfiles /\%D7\%93\%D7\%95\%D7\%97\%20\%D7\%A1\%D7\%95\%D7\%A4\%D7\%99\%20 \%D795\%D7\%99\%D7\%9\%D7\%9\%D7\%9\%D7\%9\%D7\%94\%D7\%94\%D7\%A7\%D7\%A9 \%D7\%9\%D7\%9\%.pdf. (in Hebrew)

${ }^{45}$ Ten-Brink, "Big Brother Is Dead, But Viewers Are Still Prisoners," Time Out 2016. http://timeout.co.il. (in Hebrew)

${ }^{46}$ Noa Lavie, "Between Reality and Drama': Quality in the Eyes of TV Creators," Israeli Sociology 19 (2, 2018): 99-120 (In Hebrew).

${ }^{47}$ David Hesmondhalgh and Anamik Saha, "Race, Ethnicity and Cultural Production," Popular Communication 11 (3, 2013): 179-95.

${ }^{48}$ Jason Toynbee, Making Popular Music: Musicians, Creativity and Institutions (London: Arnold, 2000).

${ }^{49}$ Luc Boltanski, On Critique: Sociology of Emancipation (Cambridge: Polity Press, 2011).

${ }^{50}$ Luc Boltanski and Laurent Thévenot, On Justification: Economies of Worth (Princeton, NJ: Princeton University Press, 2006).

${ }^{51}$ Asher Shkedi, Words That Try to Touch: Qualitative Research-Theory and Practice (Tel Aviv: Ramot, 2003). (in Hebrew)

${ }^{52}$ Zeev Sternhell, The Founding Myths of Israel: Nationalism, Socialism, and the Making of the Jewish State (Princeton, NJ: Princeton University Press, 2009).

${ }^{53}$ Anat First and Havi Inbar-Lankri, Absent and Present during Peak Viewing: A Follow up Study (Jerusalem: The Second Authority for Television and Radio, 2013) (in Hebrew).

${ }^{54}$ Anne O’Brien, "Producing Television and Reproducing Gender," Television \& New Media 16 (3, 2015): 259-74.

${ }^{55}$ Anamik Saha, Race and the Cultural Industries (Cambridge: Polity Press, 2018).

${ }^{56}$ Full disclosure: This research was financed by a grant from Israel's Second Authority for Television and Radio. This was a component I took into account, investing special effort in being as objective as possible. Furthermore, my personal connection to some of the creators (Yoram Zak, Yael Avineri, Rani Saar, and another interviewee who asked to remain anonymous) dates back many years. In my analysis of the data, I have taken pains to remain strictly neutral and not to allow my former acquaintance to affect my findings in any way. I would also point out that being a TV actress prior to joining the academic world made it easier to gain inside access to members of the industry. 
${ }^{57}$ The creators are named because in many cases they are so closely identified with their shows that anonymous quoting would be almost impossible. Furthermore, most of them agreed to be identified.

58 "Me'usharot" was categorized as "elite" content by the Second Authority, which led to an uproar in the social media (Tucker, 2014). This categorization was possible because Israel distinguishes between reality shows and "docu-reality." The latter are reality programs which are more documentary in nature, without competition or texting from the audience. Abroad, these programs are known as "docu-soap opera," that is, a nonscripted soap opera.

${ }^{59}$ Fabrizio Perretti and Giacomo Negro, "Mixing Genres and Matching People: A Study in Innovation and Team Composition in Hollywood," Journal of Organizational Behavior 28 (5, 2007): 563-86.

${ }^{60}$ Virginia Braun and Victoria Clarke, "Using Thematic Analysis in Psychology," Qualitative Research in Psychology 3 (2, 2006): 77-101.

${ }^{61}$ Biltereyst, 2004, 97.

${ }^{62}$ Yehouda Shenhav and Yossi Yonah, Racism in Israel (Jerusalem: Van Leer Institute and Hakibbutz Hameuchad, 2008). (in Hebrew)

${ }^{63}$ Shyon Baumann, "Intellectualization and Art World Development: Film in the United States," American Sociological Review 66 (2001): 404-26.

${ }^{64}$ James Hay and Laurie Ouellette, Better Living through Reality TV: Television and Post-Welfare Citizenship (Oxford: Blackwell, 2008).

${ }^{65}$ David Hesmondhalgh, Cultural Industries. 2nd ed. (London: SAGE, 2007).

\section{Bibliography}

Aslama, Mina, and Mervi Pantti. "Flagging Finnishness: Reproducing National Identity in Reality Television." Television \& New Media 8 (2007): 49-67.

Averbach, Lior. "We Wanted to Bring a Woman in Her Eighth Month into the House and Have Her Give Birth There. I Believe It Will Happen One Day." Globes, April 23, 2012. http:// www.mako.co.il/tv-bigbrother/season4-articles/Article-8314ae45a9fd631006.htm. (in Hebrew)

Bar-Gur, Ayelet. Israeli Soap Opera, from Ramat Aviv Gimmel to Ha'alufa. Tel Aviv: Resling, 2011, 67-182. (in Hebrew)

Baumann, Shyon. "Intellectualization and Art World Development: Film in the United States." American Sociological Review 66 (2001): 404-26.

Bennett, Tony. "Distinction on the Box: Cultural Capital and the Social Space of Broadcasting." Cultural Trends 15 (2006): 193-212.

Boltanski, Luc. On Critique: Sociology of Emancipation. Cambridge: Polity Press, 2011.

Boltanski, Luc, and Laurent Thévenot. On Justification: Economies of Worth. Princeton, NJ: Princeton University Press, 2006.

Boltanski, Luc, and Eve Chiapello. The New Spirit of Capitalism. New York: Verso, 2007. 
Bourdieu, Pierre. Distinction: A Social Critique on the Judgment of Taste. Boston, MA: Harvard University Press, 1984.

Bourdieu, Pierre. The Field of Cultural Production. Oxford: Polity Press, 1993.

Braun, Virginia, and Victoria Clarke. "Using Thematic Analysis in Psychology." Qualitative Research in Psychology 3, no. 2 (2006): 77-101.

Conde, Idalina. "Artists as Vulnerable Workers." CIES e-Working Paper N. 71/2009, 2009. http://www.cies.iste.pt/destaques/documents/CIES-WP71_Conde_001.pdf.

Couldry, Nick. "Reality TV, or the Secret Theater of Neoliberalism." Review of Education, Pedagogy and Cultural Studies 30 (2008): 3-13.

Couldry, Nick, and Jo Littler. "Work, Power and Performance: Analyzing the 'Reality' Game of The Apprentice." Cultural Sociology 5 (2011): 263-79.

Deery, June. "Reality TV as Advertainment." Popular Communication 2, no, 1 (2013): 1-20.

Deuze, Mark. "Work in Media." Media Industries 1 (2014). https://quod.lib.umich.edu/m/ mij/15031809.0001.201/--work-in-the-media?rgn=main; view=fulltext.

Donnelly, Kevin. "Reality." In The Television Genre Book, edited by G. Creeber, T. Miller, and J. Tulloch, 134-39. London: BFI, 2008.

Gaoni, Yael. "Industry Executives Try to Predict: Will Regulatory Focus Save Commercial Television from Collapse?" Globes, March 2, 2009. http://www.globes.co.il/news / article.aspx?did=1000429909. (in Hebrew)

Gitlin, Todd. "The Hegemonic Process in Television Entertainment Broadcasting." In Mass Communications: Currents and Schools of Thought, edited by D. Caspi, 144-64. Tel Aviv: Open University, 1995. (in Hebrew)

Hagai, Haim, and Roy Davidson. "It's Hard to Dream Anymore: The Career Structure of Screenwriters in the Israeli Film and Television Industry." Media Frameworks 13 (2014): 63-84. (in Hebrew)

Hall, Alice. "Viewers' Perceptions of Reality Programs." Communication Quarterly 54, no. 2 (2006): 191-211.

Hall, Alice. "Perceptions of the Authenticity of Reality Programs and Their Relationships to Audience Involvement, Enjoyment, and Perceived Learning." Journal of Broadcasting E Electronic Media 4 (2009): 515-31.

Harlap, Itay. Television Drama in Israel: Identities in Post-TV Culture. London: Bloomsbury, 2017.

Hay, James, and Laurie Ouellette. Better Living through Reality TV: Television and PostWelfare Citizenship. Oxford: Blackwell, 2008.

Harney, Stefano. "Creative Industries Debate: Unfinished Business: Labour, Management, and the Creative Industries." Cultural Studies 24, no. 3 (2010): 431-44.

Hesmondhalgh, David. Cultural Industries. 2nd ed. London: SAGE, 2007.

Hesmondhalgh, David. "Politics, Theory, and Method in Media Industries Research." In Media Industries: History, Theory and Method, edited by Jennifer Holt and Alisa Perren, 245-55. Chichester: Blackwell Publishing, 2009. 
Hesmondhalgh, David, and Sarah Baker. "Creative Work and Emotional Labor in the Television Industry." Theory, Culture E Society 25, no. 7-8 (2008): 97-118.

Hesmondhalgh, David, and Sarah Baker. "A Very Complicated Version of Freedom: Conditions and Experiences of Creative Labour in Three Cultural Industries." Poetics 38 (2010): 4-20.

Hesmondhalgh, David, and Anamik Saha. "Race, Ethnicity and Cultural Production." Popular Communication 11, no. 3 (2013): 179-95.

Holmes, Su. "'Reality Goes Pop!' Reality TV, Popular Music, and Narratives of Stardom in Pop Idol." Television E New Media 5, no. 2 (2004): 147-72.

Jenner, Mareika. "Binge-Watching: Video-on-Demand, Quality TV and Mainstreaming Fandom." International Journal of Cultural Studies 20, no. 3 (2015): 304-20.

Jenner, Mareika. "Is This TVIV? On Netflix, TVIII and Binge-Watching." New Media E Society 18, no. 2 (2016): 257-73.

Kavka, Misha. Reality TV. Edinburgh: Edinburgh University Press, 2012.

Krijnen, Tony, and Ed Tan. "Reality TV as a Moral Laboratory: A Dramaturgical Analysis of 'The Golden Cage."' Communications 34 (2009): 449-72.

Lavie, Noa. "'Between Reality and Drama': Quality in the Eyes of TV Creators." Israeli Sociology 19, no. 2 (2018): 99-120 (In Hebrew).

Lavie, Noa. “'Justifying Trash': Regulating Reality TV in Israel." Television E New Media 20, no. 3 (2019): 219-40.

Lavie, Noa. "'Reality' Television Critique in Israel: How 'Quality' Became 'Morality'." Cultural Sociology 10, no. 4 (2016): 502-22.

Lavie, Noa, and Alexander Dhoest. "Quality Television in the Making: The Cases of Flanders and Israel." Poetics 52 (2015): 64-74.

Lavie, Noa, and Israeli Drama. "Constructing the Israeli 'Quality' Television Series as an Art Form." Media Culture and Society 37, no. 1 (2015): 19-34.

Mayer, Vicki. "New Television and Media?" Television E New Media 12, no. 2 (2011): 95-100.

Magder, Ted. "Television 2.0: The Business of American Television in Transition." In Reality TV: Remaking Television Culture, edited by Susan Murray and Laurie Ouellette, 141-64. New York: New York University Press, 2009.

Mathijs, Ernest. "Big Brother and Critical Discourse: The Reception of Big Brother Belgium." Television E New Media 3, no. 3 (2002): 311-22.

McCabe, Janet, and Kim Akass, eds. Quality TV: Contemporary American Television and Beyond. London: I.B. Tauris, 2007.

Mittell, Jason. "Complex TV": The Poetics of Contemporary Television Storytelling. New York: New York University Press, 2015.

Moran, Albert. "Makeover on the Move: Global Television and Programme Formats." Journal of Media \& Cultural Studies 22, no. 4 (2008): 459-69. 
Mossig, Ivo. Regional Employment Growth in the Cultural and Creative Industries in Germany 2003-2008. European Planning Studies 19, no. 6 (2011): 967-90.

Murray, Susan, and Laurie Ouellette. Reality TV: Remaking Television Culture. New York: New York University Press, 2009.

Neiger, Motti. "Cultural Oxymora: The Israeli Idol Negotiates Meanings and Readings." Television E New Media 13, no. 6 (2012): 535-50.

Nelson, Robin. "Quality Television: 'The Sopranos Is the Best Television Drama Ever . . . in My Humble Opinion." Critical Studies in Television 1, no. 1 (2006): 25.

O’Brien, Anne. "Producing Television and Reproducing Gender." Television E New Media 16, no. 3 (2015): 259-74.

Oren, Tasha, and Sharon Shahaf. Global Television Formats: Understanding Television across Borders. New York: Routledge, 2013.

Perretti, Fabrizio, and Giacomo Negro. "Mixing Genres and Matching People: A Study in Innovation and Team Composition in Hollywood." Journal of Organizational Behavior 28, no. 5 (2007): 563-86.

Raphael, Chad. "The Political-Economic Origins of Reali-TV." In Reality TV: Remaking Television Culture, edited by Susan Murray and Laurie Ouellette, 119-36. New York: New York University Press, 2009.

Resnick, Julia, and Michal Frankel. "From Critical Sociology to Sociology of Criticism: The Pragmatist Sociology of Luc Boltanski." Theory and Criticism 17 (2000): 101-22. (in Hebrew)

Saha, Anamik. Race and the Cultural Industries. Cambridge: Polity Press, 2018.

Segev, Meital, and Tali Levy, eds. Second Authority Report, 2009. Jerusalem: The Second Authority for Television and Radio, 2010. http://www.rashut2.org.il/editor/upload files/Doch\%202009.pdf. (in Hebrew)

Shenhav, Yehouda, and Yossi Yonah. Racism in Israel. Jerusalem: Van Leer Institute and Hakibbutz Hameuchad, 2008. (in Hebrew)

Shkedi, Asher. Words That Try to Touch: Qualitative Research-Theory and Practice. Tel Aviv: Ramot, 2003. (in Hebrew)

Skeggs, Beverly. "The Moral Economy of Person Production: The Class Relations of SelfPerformance on Reality Television." The Sociological Review 57, no. 4 (2009): 626-44.

Sternhell, Zeev. The Founding Myths of Israel: Nationalism, Socialism, and the Making of the Jewish State. Princeton, NJ: Princeton University Press, 2009.

The Second Authority for Television and Radio. Second Authority for Television and Radio Law. 1990. http://www.rashut2.org.il/editor/UpLoadLow/b-55.pdf

Thompson, Robert J. Television's Second Golden Age: From Hill Street Blues to ER. Syracuse, NY: Syracuse University Press, 1997.

Ten-Brink. "Big Brother Is Dead, But Viewers Are Still Prisoners." Time Out 2016. http:// timeout.co.il (in Hebrew) 
Tokatli, Oren. Communication Policy in Israel . Tel Aviv: The Open University, 2000. (in Hebrew)

Toynbee, Jason. Making Popular Music: Musicians, Creativity and Institutions. London: Arnold, 2000.

Tucker, Nati. "Reality Dominates Television in Israel." The Marker, May 23, 2013. http:// www.themarker.com/advertising/1.2027656. (in Hebrew)

Tucker, Nati. "Me'usharot Is an Elite Show? Regulation Gone Bankrupt." The Marker, April 25, 2014. http://www.themarker.com/markerweek/1.2304395. (in Hebrew)

Ursell, Gillian."Television Production: Issues of Exploitation, Commodification and Subjectivity in UK Television Labor Markets." Media Culture and Society 22, no. 6 (2000): 805-25.

Waiman, Gabi, Yonatan Cohen, and Hermann Shitrit. "Reality Shows in Israel: From Reality to Imagination, Innocence to Manipulation, Public to Private." Research Report for the Second Authority. 2007. http://www.rashut2.org.il/editor/uploadfiles/ \%D7\%93\%D7\%95\%D7\%97\%20\%D7\%A1\%D7\%95\%D7\%A4\%D7\%99\%20\%D795\%D7\%9 9\%D7\%9\%D7\%9\%D7\%9\%D7\%9\%D7\%94\%D7\%94\%D7\%A7\%D7\%A9\%D7\%9\%D7\%9\% .pdf. (in Hebrew)

Waisbord, Silvio. "McTV: Understanding the Global Popularity of Television Formats." Television \& New Media 5, no. 4 2004: 359-83.

Yin, Robert K. Case Study Research: Design and Method. 4th ed. Thousand Oaks, CA: SAGE, 2009. Yuran, Noam. Channel 2-The New Statehood. Tel Aviv: Resling, Patish, 2001. (in Hebrew)

\section{Interview Index (Conducted in Hebrew, listed alphabetically)}

Avneri, Yael. (2013). Interview in Tel Aviv, April 2013.

Ben Dor, Orna. (2013). Interview in Tel Aviv, April 2013.

Glam, Ami (2014). Interview in Tel Aviv, October 2014.

Sa'ar, Rani. (2014). Interview in Tel Aviv, October 2014.

Sarfati, Tsedi. (2014). Interview in Tel Aviv, September 2014.

Weitzman, Dan. (2014). Interview in Tel Aviv, June 2014.

Yaffe, Avi. (2013). Interview in Ramat Gan, April 2013.

Zafir, Yoav. (2013). Interview in Tel Aviv, April 2013.

Zak, Yoram. (2014). Interview in Tel Aviv, May 2014.

An interview which was conducted in Tel Aviv with an assistant creator of Big Brother in September 2014. 